\title{
Correction to: Peasant Farming, a Refuge in Times of Crises
}

\author{
Angela Hilmi $^{1} \cdot$ Sara Burbi ${ }^{1}$
}

Published online: 6 November 2018

(C) Society for International Development 2018

\section{Correction to: Development (2016) 59:229-236 https://doi.org/10.1057/s41301-017- 0109-6}

Due to an unfortunate mistake, the authors' affiliation has been omitted. The affiliation is: Centre for Agroecology, Water and Resilience; Ryton-on-Dunsmore, UK
Centre for Agroecology, Water and Resilience (CAWR), Coventry University

Ryton Organic Gardens, Wolston Lane

Ryton-on-Dunsmore, Coventry, CV8 3LG, United Kingdom

We apologise for this mistake.

The original article can be found online at https:// doi.org/10.1057/s41301-017-0109-6.

$\triangle$ Angela Hilmi

ab9326@coventry.ac.uk; ab9735@coventry.ac.uk

1 Centre for Agroecology, Water and Resilience (CAWR), Coventry University, Ryton Organic Gardens, Wolston Lane, Ryton-on-Dunsmore, Coventry CV8 3LG, UK 